\title{
核融合炉心内における高速荷電粒子に詨する フォッカー・プランク方程式の数值解法
}

$\begin{array}{llllll}\text { 正員 } & \text { 桂 } & \text { 井 } & & \text { 誠 } & \text { (東京大) } \\ \text { 非会員 } & \text { 片 山 } & \text { 弘 } & \text { 造 } & \text { (東京大) } \\ \text { 准 員 } & \text { 福 } & \text { 良 } & \text { 昌 } & \text { 敏 } & \text { (東京大) }\end{array}$

\section{1.はじめに}

核融合研究は大形トカマクによる零出力条件の達成 が期待される段階にきている。このような核反応領域 での㤽心プラズマ研究においては，内部存在する亮 速荷電粒子（例えば $\alpha$ 粒子）の举動を解析するとと が求められ(1)，それらに対する速度分布関数の時間変 化をフォッカー・プランク方程式を用いて計算しなく てはならない(1)(2)。

従来，その近似的取り扱い法として，一次元速度 (v)空間のむとでの減速理論( ${ }^{(3)}$ や，ガウス形関数近似 法(4)などか提案されてきたが，より筷密な解析を行な う場合，それらは不十分である。すなわち，トカマク 磁界配位に㨟いて高速荷電粒子の損失は非等方的であ って, 速度の電流 (プラズマ電流) 方向成分を び, それに対する垂淔成分を $v_{\perp}$ で表わすと，分布関数 は $f(v, \zeta, t)$ ，閉し込わ時間は $\tau_{r}(v, \zeta)$ と表わされる から，二次元速度空間上での解析が要求される。ここ でข,らは

$$
\begin{aligned}
& v=\sqrt{v_{\|}{ }^{2}+v_{\perp}{ }^{2}} \\
& \zeta=v_{\|} / v=\cos \chi
\end{aligned}
$$

である。フォッカー・ブランク方程式を用いて $f(v, \zeta ，$ t)計算するには通常差分法が用いられるが，一般的 にいってプログラミングが大変なうえ, 計算時間も長

Numerical Solutions of the Fokker-Planck Equation for the Velocity.Distribution-Function of Supra.Thermal Ions in Fusion Plasmas. By Makoto Katsurai, Member, Kouzo Katayama, Non-member \& Masatoshi Fukura, Associate (Faculty of Engineering. The University of Tokyo).

桂击 䟤: 正是, 菓京大学工学部

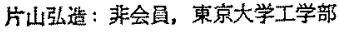

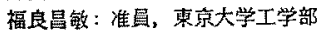

いという実際上の䦗題を有している。

そこで，本論文においては文献（4)で提案した手法 を二次元問題に拡張し，常微分方程式を用いてインパ ルス応答 (グリーン関数) を求めるという新たな手法 を確立して，その有用性を示したものである。

\section{2. フォッカー・プランク方程式 ${ }^{(5)}$}

妒心内の高速荷電粒子に詨するフォッカー・プラン ク方程式は $f(v, \zeta, t)$ 效し

$$
\begin{aligned}
\frac{\partial f}{\partial t}= & \frac{1}{\tau_{s}} \frac{1}{v^{2}} \frac{\partial}{\partial v}[A(v) f]+\frac{1}{\tau_{s}} \frac{1}{2 v^{2}} \frac{\partial^{2}}{\partial v^{2}}[B(v) f] \\
& +\frac{1}{\tau_{s}} \frac{C}{v^{3}} \frac{\partial}{\partial \zeta}\left[\left(1-\zeta^{2}\right) \frac{\partial f}{\partial \zeta}\right]-\nu(v, \zeta) f \\
& +S(v, \zeta, t) \ldots \ldots \ldots \ldots \ldots \ldots \ldots \ldots(3)
\end{aligned}
$$

ここで, $\nu(\nu, \zeta): \nu \equiv 1 / \tau_{f}$ で定義される損失 率, $S(v, \zeta, t)$ : 発生率, $\tau_{s}$ はスピシ>ーD 減速時閬

上記の $A(v) ， B(v) ， C$ および ）は炏式で与 えられる(MKS 単估系) ${ }^{(6)(7)}$ 。

$$
\begin{aligned}
& A(v)=v^{3}+v_{c}{ }^{3} \text {. } \\
& B(v)=\left(\frac{m_{e}}{m_{f}} v_{e}{ }^{2}+\frac{m_{i}}{m_{f}} \frac{v_{c}^{3} v_{i}^{2}}{v^{3}}\right) v^{2} \\
& C=\frac{m_{i}}{2 m_{f}} \frac{Z_{\text {eff }}(Z)}{\left[Z c_{c}^{3}\right.} \\
& \tau_{s}=\frac{3 \pi^{3 / 2} \varepsilon_{0}^{2} m_{f} m_{e} v_{e}^{3}}{n_{e} e^{4} Z_{f}{ }^{2} \ln A}
\end{aligned}
$$




$$
\begin{aligned}
\frac{1}{2} m_{f} v_{c}{ }^{2}= & \left(\frac{3 \sqrt{\pi}}{4}\right)^{2 / 3} k T_{e}\left(\frac{m_{f}}{m_{e}}\right)^{1 / 3} \\
& \times\left(\frac{m_{f}}{m_{i}}\right)^{2 / 3}[Z]^{2 / 3} \ldots \ldots .
\end{aligned}
$$

$Z_{f}$ は高速荷電粒子の荷電量, $Z_{\text {eff }}$ と〔Z〕は

$$
\begin{aligned}
& Z_{\mathrm{eff}}=\frac{1}{n_{e}} \sum_{j} n_{j} Z_{j}{ }^{2} \ldots \ldots . . . \\
& 〔 Z 〕=\frac{1}{n_{e}} \sum_{j} n_{j} Z_{j}{ }^{2}\left(\frac{m_{i}}{m_{j}}\right)
\end{aligned}
$$

であり， $\sum_{j}$ はイオンの全種に対する和である。

次に $f(v, \zeta, t)$ と $S(v, \zeta, t)$ に関してルジャンドル 展開を行なう。すなわち，

$$
\begin{aligned}
& f(v, \zeta, t)=\sum_{l=0}^{\infty} f_{l}(v, t) P_{l}(\zeta) \\
& S(v, \zeta, t)=\sum_{l=0}^{\infty} S_{l}(v, t) P_{l}(\zeta)
\end{aligned}
$$

(11)，(12)式を(3)式代代入すると

$$
\begin{aligned}
\frac{\partial f_{l}}{\partial t}= & \frac{1}{\tau_{s}} \frac{1}{v^{2}} \frac{\partial}{\partial v}\left[A(v) f_{l}\right] \\
& +\frac{1}{\tau_{s}} \frac{1}{2 v^{2}} \frac{\partial^{2}}{\partial v^{2}}\left[B(v) f_{l}\right]-\frac{C}{\tau_{s}} \frac{l(l+1)}{v^{3}} f_{l} \\
& -\sum_{k=0}^{\infty} E_{l k}(v) f_{k}+S_{l}(v, t) \ldots \ldots \ldots(13)
\end{aligned}
$$

を得る。こしで，

$$
E_{l k}(v)=\frac{2 l+1}{2} \int_{-1}^{1} \nu(v, \zeta) P_{l}(\zeta) P_{k}(\zeta) d \zeta
$$

である。なお，参考のために高速荷電粒子電界が作 用するような場合の公式を付録に示しておく。

\section{3. インパルス応答に対する発展方程式}

本諭文の主目的は，(13)式の $f_{l}(v, t)$ を解くにあた って，そのインパルス応答関数として文献（4）之同 様ガウス形関数を採用し，その有効性を検証するとと にある。すなわち，(13)式の $S_{t}(v, t)$ の $t=0, v=v_{0}$ でのインパルス関数を $\delta$ 関数を用いて

$$
S_{I l}(v, t)=S_{t_{0}} \delta\left(v-v_{0}\right) \delta(t)
$$

と表わし，天心忘答を

$$
\begin{aligned}
f_{n l}(v, t)= & \frac{1}{2 \pi v^{2}} \frac{n_{I l}(t)}{\sqrt{2 \pi \bar{F}_{l}(t)}} \\
& \times \exp \left\{-\frac{\left[v-v_{n}(t)\right]^{2}}{2 F_{l}(t)}\right\} .
\end{aligned}
$$

で近似する。この関数は密度に相当する $n_{I l}(t)$, 中心 速度に対応する $v_{n l}(t)$ ，てして分布の広がり $F_{l}(t)$ の 三つの時間関数によって一意的に決定されるので，基
本式 (3)のインパルス応答を解くととは，各しに対す るこの三者を決めることに䂻着される。

ここで，任意の物理量 $X(v, t)$ (ただし， $v, t$ 亿関 し滑らかな関数とする）の $l$ 成分モーメントを次のよ うに定義する。

$$
\begin{aligned}
\langle X\rangle_{l} & =\int_{0}^{\infty} X(v, t) f_{l l}(v, t) 2 \pi v^{2} d v \\
& \simeq \int_{-\infty}^{\infty} X(v, t) f_{I l}(v, t) 2 \pi v^{2} d v
\end{aligned}
$$

本来 $v>0$ であるが，(17)式に打いては以下の計算

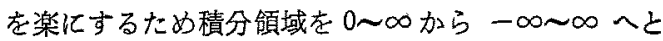
変更している。実際問題として, 本研究の対象となる 娍速過程において $v<0$ での(16)式の值は無視できる 加ら，上記の上うな積分領域の変更が許される。さ て，(17)式のモーメントに関し次の公式が導かれる。

$$
\begin{aligned}
& \langle 1\rangle_{l}=n_{l l}(t) \\
& \langle v\rangle_{l}=n_{l l}(t) v_{I l}(t) \\
& \left\langle\left(v-v_{n}\right)\right\rangle_{l}=0 \text {. } \\
& \left.\left\langle v-v_{l l}\right)^{2}\right\rangle_{l}=n_{I l}(t) F_{l}(t) \ldots \\
& \left\langle\left(v-v_{l l}\right)^{4}\right\rangle_{l}=3 n_{I l}(t) F_{l}(t)^{2}
\end{aligned}
$$

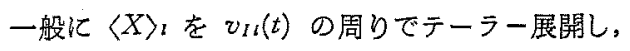

$$
\begin{aligned}
\langle X\rangle_{l} \simeq & X\left(v_{l l}(t), t\right) n_{I l}(t) \\
& +\frac{1}{2}\left(\frac{\partial^{2} X}{\partial v^{2}}\right)_{v_{I l}(t)} n_{I l}(t) F_{I l}(t)
\end{aligned}
$$

$$
\left\langle\left(v-v_{I l}(t) X\right\rangle_{l}=\left(\frac{\partial X}{\partial v}\right)_{v_{I l}(t)} n_{I l}(t) F_{l}(t)\right.
$$

$$
\begin{aligned}
& \left\langle\left(v-v_{I l}(t)\right)^{2} X\right\rangle_{l}=X\left(v_{I l}(t), t\right) n_{I l}(t) F_{l}(t) \\
& \quad+\frac{1}{2}\left(\frac{\partial^{2} X}{\partial v^{2}}\right)_{v v_{l}(t)} n_{I l}(t) F_{l}(t)^{2} \ldots \ldots \ldots(25)
\end{aligned}
$$

以上の公式を利用し，(13)式の $1 ，\left(v-v_{I t}(t)\right)$ およ び $\left(v-v_{n}(t)\right)^{2}$ 亿対するニーメントを計算すると， $n_{I l}(t), v_{I l}(t), F_{l}(t)$ に対する次の常徽分形発展方程 式を得ることができるとここで，時間関数を示す $(t)$ の記号は略す了。

$$
\begin{gathered}
\frac{d n_{I l}}{d t}=-\frac{C l(l+1)}{\tau_{s}} \frac{n_{I l}}{v_{I l}{ }^{3}}-\sum_{i=0}^{\infty} E_{l i}\left(v_{1 i}\right) n_{l i} \\
\ldots \ldots \ldots \ldots \ldots \ldots \ldots \ldots \ldots \ldots(26) \\
\frac{d v_{I l}}{d t}=-\frac{1}{\tau_{s}} \frac{A\left(v_{I l}\right)}{v_{l l}^{2}}-\sum_{i=0}^{\infty}\left(v_{l i}-v_{I l}\right) \frac{n_{I i}}{n_{I l}} E_{l i}\left(v_{I i}\right)
\end{gathered}
$$




$$
\begin{aligned}
\frac{d F_{l}}{d t}= & \frac{1}{\tau_{s}} \frac{B\left(v_{I l}\right)}{v_{l l}{ }^{2}} \\
& +\frac{1}{\tau_{s}}\left[\frac{1}{2} \frac{\partial^{2}}{\partial v^{2}}\left(\frac{B(v)}{v^{2}}\right)-2 \frac{\partial}{\partial v}\left(\frac{A(v)}{v^{2}}\right)\right]_{v_{I l}} F_{l} \\
& -\sum_{i=0}^{\infty}\left[\left(v_{I i}-v_{l l}\right)^{2}+\left(F_{i}-F_{l}\right)\right] \frac{n_{I i}}{n_{l l}} \\
& \times E_{l i}\left(v_{l i}\right) \ldots \ldots \ldots \ldots \ldots \ldots \ldots \ldots(28)
\end{aligned}
$$

\section{4. 数 值計算}

(26) ～(28) 式の連立常微分方程式を数值計算する場 合の諸注意について述べる。まず問題となるのは，損 失項についての $E_{l k}(v) の$ 積分(14)式である。いま

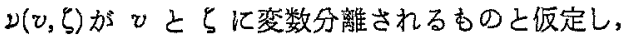

$$
\nu(v, \zeta)=V(v) T(\zeta)
$$

とする。実際上は図 1 のような損失領域を $v_{n}-v_{\perp}$ 面 上で仮定し

$$
\begin{aligned}
& V(v)=\left\{\begin{array}{cc}
0 & \left(v<v_{m}\right) \\
V_{0} & \left(v>v_{m}\right)
\end{array}\right) \\
& T(\zeta)= \begin{cases}1 & \left(\zeta_{1}<\zeta<\zeta_{2}\right) \\
0 & (\text { 上記以外 })\end{cases}
\end{aligned}
$$

とする。とのとき

$$
E_{l i}(v)=V(v)\left\{\frac{2 l+1}{2} \int_{-1}^{1} T(\zeta) P_{l}(\zeta) P_{i}(\zeta) d \zeta\right\}
$$

である。しかし，(31)式の $T(\zeta)$ に関して上式の皘分

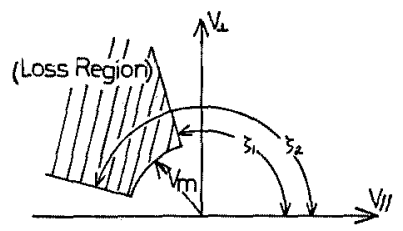

図 1 高速荷電粒子に対する速度空間上の 損失領域（斜線部）の設定

Fig. 1. Loss regions in velocity space for high energy charged particles.
は収束性が非常に悪い。そこで

$$
\begin{aligned}
& T(\zeta)=\exp \left[-a(\zeta-\bar{\zeta})^{2}\right] \\
& \bar{\zeta}=\frac{\zeta_{1}+\zeta_{2}}{2}, a=\frac{4}{\zeta_{2}-\zeta_{1}} \cdots
\end{aligned}
$$

という滑らかな関数を(31)式に代わって用いることに する。また $i$ に対する和については， $i=l$ の項が中心 となるよう

$$
\sum_{i=0}^{\infty} E_{l i}\left(v_{i}\right) \rightarrow \sum_{i=-M}^{M} E_{l, l-i}\left(v_{l-i}\right)
$$

という変形起行なう。lに関する次数は $N$ までとし， (35)式に枋ける $(l-i)$ について

$$
0 \leq(l-i) \leq N
$$

となる項のみを生加し，それ以外の項は無視する。 $M, N$ のり方については後章において議論される。

以上の手法を用いて以下，具体的問題に対する計算 結果を示す。使用した諳算機は東京大学大形計算機セ ンター所有の HITAC M $200 \mathrm{H}$ である。

\section{5. 展開法と差分法の比較}

以上導いた展開法を従来の差分法による計算と比較 する。ここで参照のために使用した差分法は強陰法 (Strong implicit method) と呼ばれ，アメリカ・オー クリッジ研究所で開発された手法である(8)。メッシュ として $120 \times 40$ をとる。

以下の計算において分布関数 $f$, 速度 $v$ について それぞれ初期 $t=0 に て f d^{3} v=1, v / v_{0}=1$ となる よう正規化されている。また，時刻 $t$ はで篻位と して計算されている。

まず最初の例として，水素プラズマ $\left(\mathrm{H}^{+}\right)$内にプラ ズマ電流之平行方向に初期エネルギー $E_{0}=500 \mathrm{keV}$ $\left(v_{0}=9.8 \times 10^{6} \mathrm{~m} / \mathrm{s}\right)$ で，同種イオンをインパルス状に 入射させた場合の分布関数の時間変化を图 2 に示す。 ここで損失項は無視し $(\nu=0), \quad T_{0}=T_{i}=10 \mathrm{keV}$, $Z_{\mathrm{eif}}=10$ としてある。この $Z_{\mathrm{efr}}$ の值はピッチ角散乱

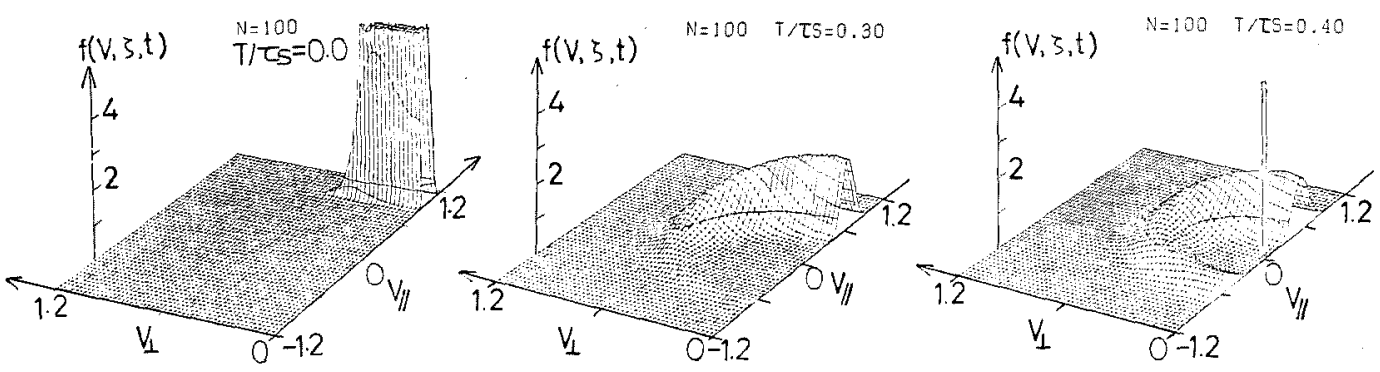

园 2 水素プラズマ中の同種高速イオンの減速過程 $\left(Z_{\mathrm{ef} f}=10\right)$

Fig. 2. Retardation of ions in hydrogen plasma $\left(Z_{\mathrm{eff}}=10\right)$. 
の効果で分布関数が広がっていく様子を強調するた め，意識的に大きめの值が指定されている。また密度

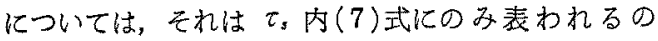
て，時刻を $\tau_{s}$ 単位で表わす場合，表には現われな い。初期条件洁，計算式(15) の $S_{10}$ を求めやすくす るため

$$
S(v, \zeta, t=0)=\frac{\delta\left(v-v_{0}\right)}{2 \pi v^{2}} \frac{N+1}{2^{N+1}}(1+\zeta)^{N}
$$

を仮定し，との坂定のもとで

$$
\left.\begin{array}{rl}
n_{I l}(0)= & \frac{2 l+1}{2^{N-l+1}} \\
& \times \sum_{i=0}^{2 i+l \leq N} \frac{(N+1) !(i+l) !}{i !(N-2 i-l) !(2 i+2 l+1) !} \\
v_{I l}(0)= & 1 \\
F_{l}(0)= & 0
\end{array}\right\}
$$

である。図 2 は $N=100$ の場合の展開法に上る計算例 であって，(a)〜（c）図と時間の経過に従ってピッチ 角散乱の効果で，分布が $v_{1}$ 方向に広がっていく様子 が良く示されている。

この結果之従来の差分法による結果とを比較したも のか図3であり，てれは図 2 の $\zeta=\cos \left(30^{\circ}\right)$ の断面で の分布の時間変化を示している。図中，実線は展開 法，破線は差分法に対応するが，減速過程中（0.1 $\left.v_{I}<1\right)$ での両結果の一致は非常に良い。

次に，より実際上重要な問題として図 4(a) 亿示す ような分布を有するDT 炬心内で等方的に発生した $\alpha$ 粒子 $\left(E_{0}=3.52 \mathrm{MeV}\right)$ ○速度分布関数の時間变化の 様子を示す。条件としては，実際の炉心条件に合わせ $T_{e}=T_{i}=10 \mathrm{keV}, Z_{\mathrm{ef} i}=3$ ，更に損失領域については (34) 式の $\zeta_{1}=\cos \left(110^{\circ}\right), \quad \zeta_{2}=\cos \left(160^{\circ}\right), V_{m}=1 \mathrm{MeV}$ 之設定した。展開法において $M=20, N=20$ とし， 差分法との比較を行なった。展開法汇対する初期条件

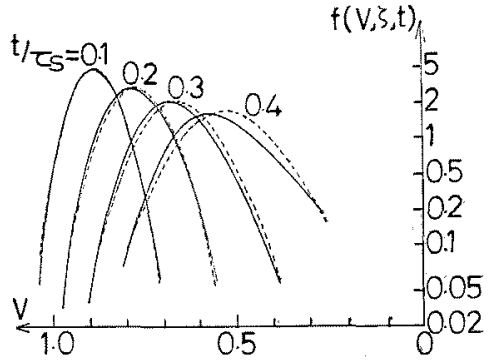

図 3 差分法(実線) 乙展開法(破線)の比較

Fig. 3. Comparison of results obtained by the difference method and by the expansion method.

は

$$
\begin{aligned}
& n_{l l}(0)=\left\{\begin{array}{cc}
0.5 & (l=0) \\
0 & (l \geq 1)
\end{array}\right\} \\
& v_{n l}(0)=1 \\
& F_{l}(0)=0
\end{aligned}
$$

である。

図 4(b)，(c) は展開法，因 5(a)，(b)は差分法に 上る時間変化の計算結果を示したむの, 図6 は再図の $\zeta=\cos \left(30^{\circ}\right)$ における分布の時間変化を並記, 比較し たものである。図 4 , 図 5 で損失領域近傍の分布を見 比べてみると，二つの計算法の結果に多小の差異が認 められる。なお，減速が十分進んだ段階において，展 開法は(17)式で採用した近似が成り立たなくなるか ら，差分法に比べ精度が落ちてくる(この領域は本研 究の対象外である)。

以上の二例に対し，二つの計算法汇関する計算所要 時間の比較を行なったものが図 7，図8で，それぞれ 图3, 図6の結果に対応，更に図8には $N=M=10$ の場合も示されている。時間刻み $\Delta t$ は $0.02 \tau_{s}$ であ る。雨図加ら，本論文で提案した展開法の計算速度が 差分法より 5〜10倍速いことが判明する。ここで注意

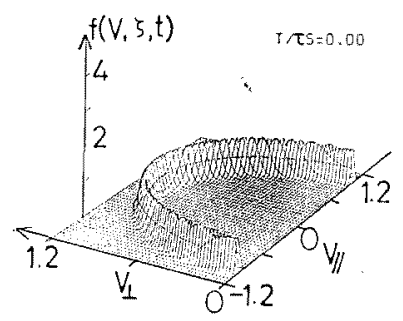

(a)

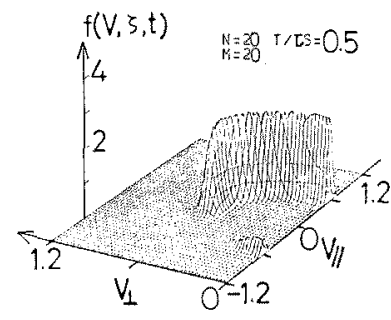

(b)

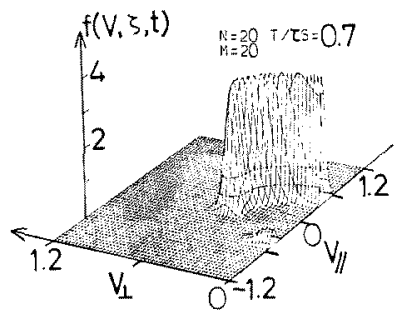

(c)

図 4 展開法による DT プラズマ内の $\alpha$ 粒子の減速計算 $\left(Z_{\mathrm{eff}}=3\right)$ 〔(a)図は初期分布〕

Fig. 4. Retardation of alpha-particles calculated by the expansion method $\left(Z_{\text {eff }}=3\right)$ [(a): initial profile $]$. 


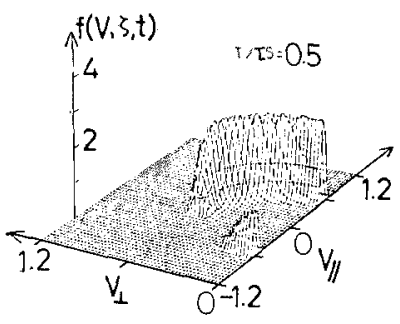

(a)

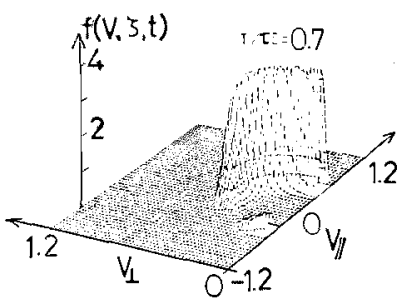

(b)

条件之初期分布は図 4 と同じ。(a)图は园 4 (b)， (b)図は図4(c) と同し時刻である。

図 5 差分法によるDT プラズマ内の $\alpha$ 粒子の隇速計算

Fig. 5. Retardation of alpha-particles calculated by the difference method on the same condition as Fig. 4.

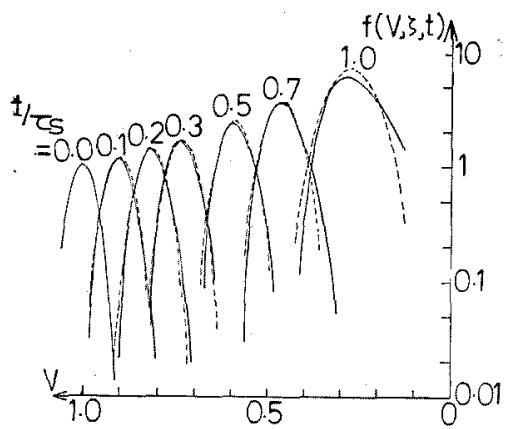

図 6 差分法(実線) と展開法 (破線) の比較

Fig. 6. Comparison of calculations by the expansion method and by the difference method.

すべき点は，展開法においては初期江損失項 (32)式の 係数計算を必要とする点であり， この所要時間は $M$ に大きく依存する。図 9 にその様子を示すが， $M \geq 20$ となると急激化計算時間加增加する。他方，展開次数 $N$ については $N \leqq 15$ 之少ない場合，求めた分布関数 には数％の波打ちが見られる一方， $N$ を增して $N$ Z30 とすると計算時間が長くなる割には精度の向上 は頭打ちさ机る。とのような考察を総合すると $M$ 〜 $N \sim 20$ というような選定が，計算能率と収束性の両

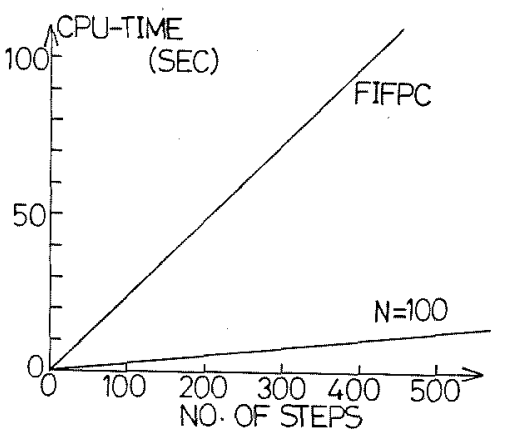

図 7 損失を無視した場合の㖕算時閻の比較

Fig. 7. Computational time for a lossless case.

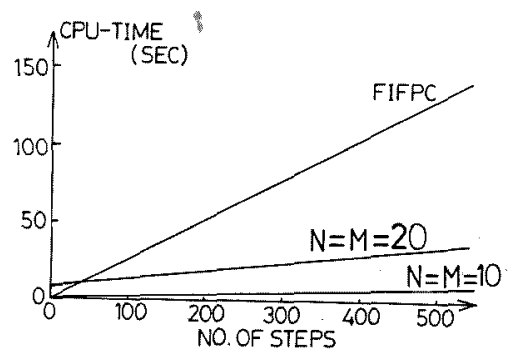

図 8 損失を考察した場合の計算時間の比較

Fig. 8. Computational time for a lossy case.

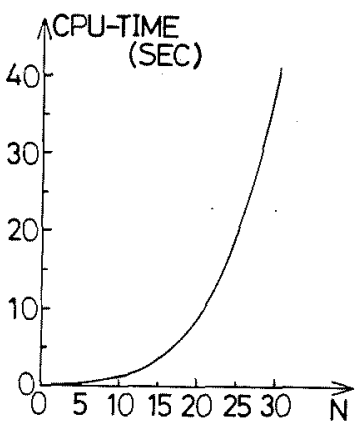

図 9 展開法におりる損失項の係数計算時間

Fig. 9. Computational time for the expansion coefficients of loss term in the expansion method.

面加ら妥当なむの之結論される。しかし，分布関数を のむのを求めるのではなく，次章で示すよう何らか の積分計算の結果を求める場合， $M \sim N \sim 10$ 程度で あっても, 上記 $M \sim N \sim 20$ の場合に比べ $5 \%$ 程度の 差異しか現的机ない。

以上の計算時間についての比較は，時間刻み幅 $\Delta t$ を $\Delta t \sim 0.02 \tau$ s とした場合であり，ての $\Delta t$ につい て本展開法において $\Delta t \sim 0.1 \tau$ s 程度まで長くしてむ 
精度は落ちない。しかし差分法においては, 上記 $\Delta t$ $\sim 0.02 \tau$ s が上限であって，それ以上 $\Delta t$ を長くする 之数值的不安定を起しすから，実際の計算速度に関し ては展開法のほうが更に有利になる。

\section{6. 応用}

本章では，トカマク形 DT 吙心プラス゚マ内の $\alpha$ 椟 子に関連した三つの問題に対する展開法の活用につい て議論してみる。

$\langle 6 \cdot 1\rangle \alpha$ 粒子速度分布関数の定常解 炣心プラ ズマ条件が一定の場合，展開法で求めたインパルス応 答を時間皘分すれば定常解を求るることができる。す なわち，発生項 $S(v, \zeta, t)$ がステッッフ関数の場合の応 答 $f_{s}(v, \zeta, t)$ を

$$
f_{s}(\nu, \zeta, t)=\int_{0}^{t} f_{I}(\tau, \zeta, t-\tau) d \tau .
$$

より計算し，十分時間が経過したときの $f_{s}(v, \zeta, t)$ を求めればそれが定常解となる。

さきの例（図 4〜図6)と同様のプラズマ条件に対す る計算例を図 10 に示す。てれは $\chi=\cos \left(30^{\circ}\right)$ に和け る分布関数の定常解への渐近過程を示したものであ り，解析的に導加れた結果(9) と良く一致している。

$\langle 6.2\rangle \alpha$ 粒子加熱の瞬時量 DT 炉の動作条件 が比較的高密度低温度領域に設定される場合， $\alpha$ 粒子 による内部加熱は粒子発生と同時に行なわれるという 近似が成り立つが, 逆に低密度で高温度領域に設定さ れる場合， $\alpha$ 粒子の減速過程中にプラズマ条件が変化 する恐机があるため， 《粒子からプラズマへのエネル ギー移行量を，その分布の時間变化を考虑して計算し なくてはならない(2)。

いま,フォッカー・プランク方程式 (3)内の $A(v)$,

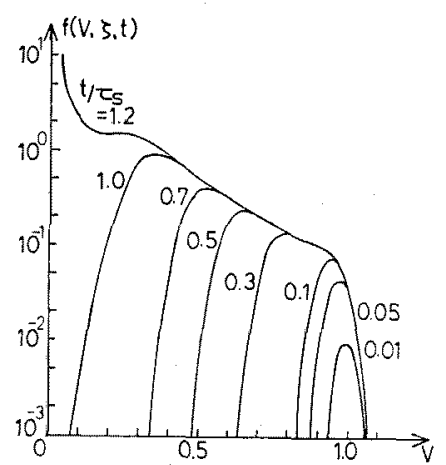

图 $10 \alpha$ 粒子の定常分布への接近の樣子

Fig. 10. Approach to a steady state distribtion function for alpha-particles.
$B(v)$ について，䉓子による項とイオンによる項をそ れぞれ $A_{e}(v) ， B_{e}(v)$ および $A_{i}(v) ， B_{i}(v)$ とする。 てれらは (4)，(5)式の右辺第 1 項招よび第 2 項に対 応する。よって， $\alpha$ 粒子から電子およびイオンへのエ ネルギー移行量 $W_{\mathrm{a}}(t), W_{i}(t)$ 恃， $t=0$ でのインパ ルス状 $\alpha$ 粒子発生に対し $k=e$ (電子), $i($ イオン) $上$ して

$$
\begin{aligned}
W_{I k}(t \mid 0) & \\
= & \int \frac{m_{f}}{2}\left(-\frac{2 A_{k}(v)}{v}+\frac{B_{k}(v)}{v^{2}}\right) \frac{1}{\tau_{s}} \\
& \times f_{I}(v, \zeta, t) 2 \pi v^{2} d v d \zeta \\
\simeq & {\left[-\frac{2 A_{k}\left(v_{I 0}\right)}{v_{I 0}}+\frac{B_{k}\left(v_{I 0}\right)}{v_{I 0}{ }^{2}}\right] \frac{m_{f} n_{I 0}}{\tau_{s}} }
\end{aligned}
$$

なる応答を示し， $l=0$ の項のみの簡単な式となる。

ところで $\alpha$ 粒子は発生後, 熱化時間 $\tau$, 程度経つ之 完全に熱化してしまう。こてで

$$
\tau_{t}=\frac{\tau_{s}}{3} \log \left[1+\left(\frac{v_{b}}{v_{c}}\right)^{3}\right]
$$

で， $\tau_{s}$ 注 (7)式のスピッァ一の娍速時間である。よっ て，時間 $t$ におりる加熱最 $W_{k}(t)$ を求めるにあたっ ては， $\left(t-\tau_{t}\right)$ から $t$ までの間に発生した全 $\alpha$ 粒子に 対するインパルス応答を亚次展開法で計算し， (41)式 の時間皘分を求めればよい。すなわち， $t=t^{\prime}$ に発生 した $\alpha$ 粒子の加熱量を $W_{I k}\left(t \mid t^{\prime}\right)$ とし

$$
W_{k}(t)=\int_{\left(t-\tau_{t}\right)}^{t} W_{I k}(t \mid \tau) d \tau
$$

この $\tau_{\iota}$ の時間幅に拈いて

$$
L=\tau_{t} / \Delta t
$$

個の計算点があり，数値計算にあたっては，それと同 数の $\alpha$ 粒子に対するインパルス応答を蓄えておく必 要がある。すなわち，各時刻において $N \times L$ 組の $\left(n_{l l}, v_{l l}, F_{l}\right)$ に対する計算を必要とする( $\alpha$ 粒子に対 しては $F_{l} \sim 0$ としてあよい)。って L〜10 とすれ ば、計算時間は単なるインパルス応答に比べ 1 けた増 加するので，時間刻み幅が同じなら，その計算時間は 差分法並みとなる。しかし実際上，展開法では時間刻 み幅を前述の上うにかなり大きくとれるから，計算速 度という点での展開法の優利性は十分確保されよう。

$\langle 6.3\rangle \boldsymbol{\alpha}$ 粒子による電流 トカマクにおける $\alpha$ 粒子の損失領域は $v_{\|}<0$ の領域に存在する ${ }^{(6)}$ 只ら， その娍速過程中に㧧いて $v_{\|}>0$ の成分が $v_{\|<0}$ の 成分より大きくなり，プラズマ電流と同じ方向のイオ ン電流を生じる。これを $\alpha$ 粒子電流と四び $I \alpha$ で表 わす。 $\alpha$ 粒子電流の計算は文献 $(10) ，(11)$ に示され 


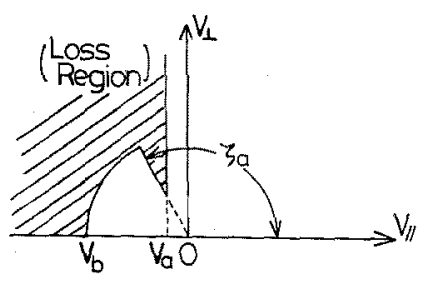

図 11 トカマク磁界内での $\alpha$ 粒子 の損失领域

Fig. 11. Loss region for alpha-particles in tokamak.

ているが，ここでは展開法を用いて計算してみる。

いま，イオン密度老 $n_{i}\left(=2 n_{D}=2 n_{T}\right)$ とし， $t=0$ においてインパルス状敒発生した $\alpha$ 粒子の态答を $i_{a}(t)$ とすると

$$
\begin{aligned}
i_{\alpha}(t)= & \frac{n_{i}^{2}}{4}\langle\sigma v\rangle_{\text {DT }} \\
& \times 2 e \int \zeta v f_{I}(v, \zeta, t) 2 \pi v^{2} d v d \zeta \\
= & \frac{e n_{i}^{2}}{3}\langle\sigma v\rangle_{\text {DT }} n_{I I} v_{I} \ldots \ldots \ldots \ldots \ldots . . . . . . .
\end{aligned}
$$

となって，l=1の項のみが残るので，物理的意味が理 解しやすく，かつ計算誤差が少なくてすむような式が 求まる。

次に，プラズマ断面内における磁気面を同心円群で 表わし，等殴力面とドリフト面もこの磁気面と一致す ると考える。トカマクに怙ける $\alpha$ 粒子の損失領域は

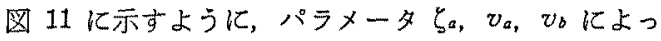
て決定されるが，それらの值は磁気面によって暴な り，一般にプラズマ周囲芯ど損失領域は広くなる。乙 てでは文献（6)の結果任従って上記パラメータを決定 し，更にをれを(29)式で近似するだめ，図12に示す ような二つの損失領域 $\nu_{a}, \nu_{b}$ の重㸚合わせと考え t。

次に，断面内でのプラズマ電流密等 $i_{p}(r)$, イオン密 度 $n_{i}(r)$, 温度分布 $T_{i}(r)$ をそれぞれ

$$
\begin{aligned}
& i_{p}(r)=i_{0}\left[1-\left(\frac{r}{a}\right)^{2}\right]^{x_{i}} \ldots \\
& n_{i}(r)=n_{0}\left[1-\left(\frac{r}{a}\right)^{2}\right]^{x_{n}} \cdots \\
& T_{i}(r)=T_{0}\left[1-\left(\frac{r}{a}\right)^{2}\right]^{x_{T}}
\end{aligned}
$$

上する。また電子についても同様の密度，温度分布を 仮定し，それぞれの磁気面に捛ける $\alpha$ 粒子電流密度 のインパルス応答 $i_{I \alpha}(r, t)$ を計算すれば，(全) $\alpha$ 粒 子電流のステップ芯答は

昭 $57-3$
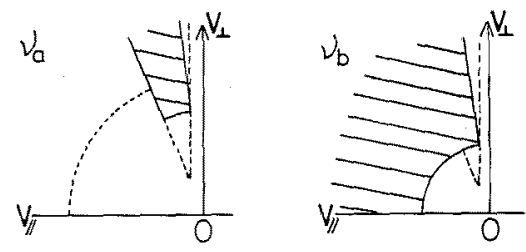

図 12 損失領域の近似的取り扱い

2.-[Fig. 12. Approximated treatment of loss regions for alpha-particles in tokamak.

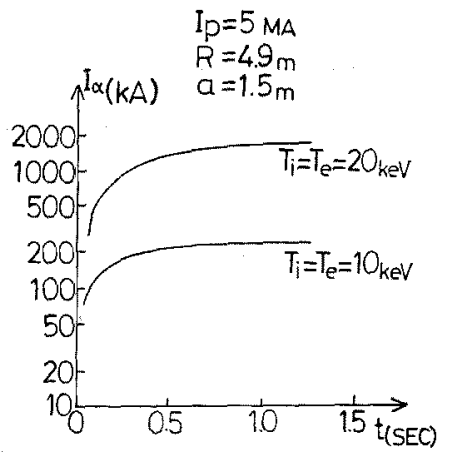

図 $13 \alpha$ 粒子電流の大きさ

Fig. 13. Plasma current by alpha-particles.

$$
I_{\alpha}(t)=\int_{0}^{t} \int_{0}^{a} i_{I_{\alpha}}(r, t-\tau) 2 \pi r d r d \tau
$$

によって計算できる。

図 13 岵プラズマ電流 $I_{p}=5 \mathrm{MA}, a=1.5 \mathrm{~m}, R / a$ $=3.3$ の場合で, 加すべての空間分布が二様 $\left(x_{i}\right.$ $\left.=x_{n}=x_{T}=0\right)$ の場合の結果を示したもので， $n_{0}=1.6 n$

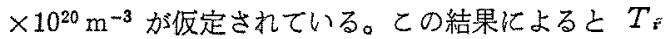
$=T_{e}=20 \mathrm{keV}$ の場合， $I_{p}$ の $5 \mathrm{MA}$ に及ばないむの の，Ia として定常的に 1. $7 \mathrm{MA}$ 程度発生するてとが 示される。

ところで，大形トカマクにおける $\alpha$ 粒子の損失は 主们周辺部の磁気面上沉机いて大きい加ら，空間分布 の影響が $I_{\alpha} に$ 対し強く効くむのと予想される。表 1 は空間分布を考慮した場合の $I_{\alpha}$ の定常値（ステップ 応答の飽和值)であり，分布によって $I_{\alpha}$ は大きく減 少し，特に実験焐 (EPR) 級 ${ }^{(12)}$ 亿なる上 $I_{\alpha} \sim 40 \mathrm{kA}$ のレベルにまで下がってしまう。逆にそれだけ中心部 の $\alpha$ 粒子閉じ込多は良いということである。

ての上うな大形トカマクにおける $I_{\alpha}$ の值は，すし あ新古典理論が予言するようなブート・ストラップ電 流(13)が励起される場合，大きな影響党炉心特性に与え る。すなわち，新古典理論によるイオンの拡散によっ てプラズマ電流の增幅が起とり，その增幅率は 10〜 
表 $1 \alpha$ 粒子によって生ずるプラズマ電流の例 Table 1. Plasma current by alpha-particles for various temperature and density spatial profiles.

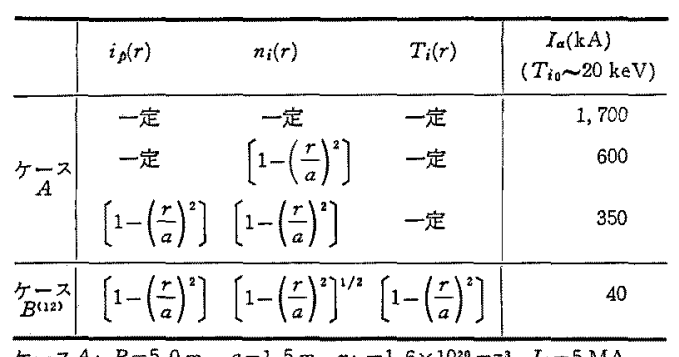

ケースA:R=5.0 m, $a=1.5 \mathrm{~m}, n_{i_{0}}=1.6 \times 10^{20} \mathrm{~m}^{-3}, I_{p}=5 \mathrm{MA}$ ケースB:R=6.8m, $a=2.3 \mathrm{~m}, \quad n_{i 0}=8 \times 10^{20} \mathrm{~m}^{-3}, I_{p}=7.2 \mathrm{MA}$

100 亿も達すると予想される(10)。すなわち，Ia 40 $\mathrm{kA}$ です，ブート・ストラップ電流は MA のけたと なり，I $I_{\alpha}$ 自身は小さくても無視できない影響をプラ ズマ閉じ込めに与えることになる。この理論の正当性 はいまのところ不明であるが，むしとのととが実験的 に確認されるようだと， I $\alpha$ に関する時間変動の計算 は炉心の動特性研究に重要な地位を占めるととにな り，それを能率良く遂行できる本提案の計算法は威力 を発揮しょう。

\section{7. 結言}

本論文にて提案した展開法を用いることによって， 非等方的損失領域を有する炣心プラズマ内の高速荷電

粒子の速度分布関数の時間応答を，常微分方程式を用 いて能率良く計算できるととが示された。展開法は， フォッカー・プランクカ程式を直接解く差分法に比ぺ プログラミングが単純なうえ，数式の物理的な解积に 沿って容易に定式化が可能である。また計算時間も差 分法より短縮される。今後, 核反応頜域にある核融合 炉心プラズマの特性を解析する際に有力な手段となる う。

(昭和 56 年 5 月 21 日受付, 同 56 年 9 月 16 日再受付)

\section{文献}

(1) Ya. I, Kalesnichenko: Nuclear Fusion, 20, 6, 727 (1980)

(2) H. Saito, et al.: Plasma Physics and Controlled Nuclear Fusion Research, IAEA-CN-35/I9-1 (1976)

(3) H. Saito, et al.: Nuclear Fusion, 17, 5, 919 (1977)

(4) M. Katsurai, et al.: J. Faculty Engng., Univ. of Tokyo $(B), 16,2,67$ (1981)

(5) 中野: プラズマ工学列題演習，第 $1,5,6$ 章，(昭49) コロ ナ社

(6) J.A. Rome, et al.: Nuclear Fusion, 16, 1, 55 (1976)

(7) D.L. Jassby: Nuclear Fusion, 17, 2, 309 (1977)

(8) R.H. Fowler, et al.: ORNL-TM-5487 (オークリッシ国 立研究所技術メも) (1976)

(9) Ya.I. Kolesnichenko: Ref. [1] \$2.4

(10) J.R. McNally: ORNL-TM-6492 (1978)

(11) Ya.L. Kalesnichenko, et al.: Nuclear Fusion, 20, 1041 (1980)

(12) N. Uckan, et al.: Proc, 6th Symp. on Engineering Problems of Fusion Research, p. 1105 (1975)

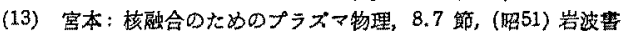
店

録

電界項がある場合の発展方程式 プラズマ電流方向の外部電界 $E_{\mathrm{ext}}$ が高速荷電粒子に作用し， $q_{f} E_{\text {ext }}$ の 力か働く場合

$$
\begin{aligned}
& \frac{\partial f}{\partial t}=(3) \text { 式右边 }-D\left[\zeta \frac{\partial f}{\partial v}+\frac{1-\zeta^{2}}{v^{2}} \frac{\partial f}{\partial \zeta}\right] \\
& D=\frac{q_{f}}{m_{f}}\left(1-\frac{[Z]}{Z_{\text {eff }}}\right) E_{\text {ext }}
\end{aligned}
$$

発展方程式は次の上うに変形される。

$$
\begin{aligned}
& \frac{d n_{n l}}{d t}=(26) \text { 式右辺 }-D\left[\frac{l(l+1)}{2 l+3} \frac{n_{l l+1}}{v_{l l+1}}-\frac{l(l+1)}{2 l-1} \frac{n_{I l-1}}{v_{l l-1}}\right] \\
& \frac{d v_{n l}}{d t}=(27) \text { 式右扨 }-D\left[\frac{l+1}{2 l+3}\left(l-1-l \frac{v_{n l}}{v_{I l+1}}\right) \frac{n_{I l+1}}{n_{l i}}-\frac{l}{2 l-1}\left(l+2-(l+1) \frac{v_{l L}}{v_{I l-1}}\right) \frac{n_{I l-1}}{n_{I l}}\right] \\
& \frac{d F_{l}}{d t}=(28) \text { 式右辺 }-D\left[\frac{l+1}{2 l+3}\left\{l \frac{\left(v_{l l+1}-v_{l l}\right)^{2}}{v_{l l+1}}-2\left(v_{I l+1}-v_{I l}\right)+l\left(2 F_{l+1} \frac{v_{I l}{ }^{2}}{v_{I l+1}{ }^{3}}-F_{l} \frac{1}{v_{I l+1}}\right)\right\} \frac{n_{I l+1}}{n_{l l}}\right. \\
& \left.-\frac{l}{2 l-1}\left\{(l+1) \frac{\left(v_{n l-1}-v_{n l}\right)^{2}}{v_{l l-1}}-2\left(v_{l l-1}-v_{l l}\right)+(l+1)\left(2 F_{l-1} \frac{v_{l l}^{2}}{v_{l l-1}{ }^{3}}-F_{l} \frac{1}{v_{l l-1}}\right)\right) \frac{n_{l l-1}}{n_{l l}}\right\}
\end{aligned}
$$

